\title{
DETERMINATION OF TYPES OF INDIVIDUALS IN APHIDS, ROTIFERS AND CLADOCERA ${ }^{1}$
}

\author{
BY A. FRANKLIN SHULL. \\ University of Michigan, Ann Arbor, Mich., U.S.A.
}

(Received March 8th, 1929.)

IN responding to the request of the editor for a review of the investigations into cycles involving alternating modes of reproduction, it has seemed wise to limit the field to the rotifers, aphids and cladocera. These three groups possess a cycle fundamentally alike. A unified discussion of them is therefore possible, even though a unified explanation has not yet been attained. Moreover, to treat adequately a larger field would require an article beyond any desirable limit of size.

\section{The cycle.}

In all three groups, reproduction is chiefly by parthenogenesis, but at times gamic females and males are produced. By these gamic forms fertilised eggs are produced which are capable of living over winter, and, in the case of the aquatic forms (rotifers and cladocera), over periods of drought. Fertilised eggs may, of course, be produced at other times. From the fertilised egg there hatches a female which is obligatorily parthenogenetic, and her offspring are all females. The nature of these females of the second generation varies somewhat, but in each of the three groups of animals there are species in which the individuals of the second generation may be either obligatorily parthenogenetic or gamic. There are some species having a "fixed" or "closed" cycle in which the generations are not subject to variations, but naturally these species will not figure largely in the investigations about to be reviewed. In the species with "open" cycles, the successive generations consist of varying proportions of obligatorily parthenogenetic and gamic forms. The gamic forms may produce fertilised eggs and the cycle be repeated. The parthenogenetic individuals of each generation continue to produce either parthenogenetic or gamic forms as long as conditions are suitable. The combination of parthenogenesis with gamic reproduction, as it occurs in these groups, was given by Leuckart in $186_{5}$ the name of Heterogony, a term still frequently used in the European literature.

Beyond these points of likeness, there are important differences. In the rotifers, the gamic female, if not fertilised, produces males from the same eggs as would, if fertilised. produce females. The gamic females therefore precede the males by one generation, and sex is absolutely bound up with the mode of reproduction. Males are produced in no other way than by unimpregnated gamic females. The gamic and parthenogenetic female rotifers are structurally alike, and cannot be distinguished until they produce offspring, except by microscopic examination of their oocytes. In the aphids, parthenogenetic females and gamic females are usually

- Contribution from the Zoological Laboratory of the University of Michigan. 
structurally distinct, though in rare cases one female may produce eggs of both kinds. Male aphids are not the sons of gamic females, but each sex is produced by certain parthenogenetic females. The parthenogenetic females of any generation, in most species, may be either winged or wingless. In most (but not all) species the gamic female is wingless and the male winged. The aphid cycle is less sharply defined, therefore, than that of the rotifers, and sex is only loosely connected with the mode of reproduction. In the cladocera, in typical cases, any female, after the one which hatches from a fertilised egg, may be either parthenogenetic or gamic or both, and if she is parthenogenetic her offspring may be either female or male.

Partly because of the presence or absence of wings, the cycle of the aphids is subject to enormous variation. The above statement with respect to them is a bare outline. Excellent statements of many of the peculiarities of their cycle are to be found in articles by Klodnitski (1912), Mordwilko (1907 a, I907 b, 1908, 1909) and Davidson (1927 $a, 1927 b$ ).

Certain features of the cycles have been discussed by Shull (1925) with special reference to the work then most recent.

Early ideas of these cycles.

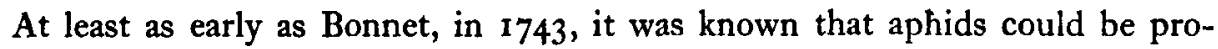
duced without sexual union of their parents. For a long time it was supposed that this reproduction might be strictly asexual, though before the middle of the nineteenth century parthenogenesis was more than suspected. However, in 1856 it was still stoutly maintained by Burnett and by von Siebold that the young of agamic aphids were produced from internal buds. Even as late as I 866 Balbiani deemed it necessary to debate this old question, and to furnish proof of parthenogenesis by demonstrating the presence of a reproductive system comparable to that of the gamic female and by showing that the embryo develops within this system (the agamic aphids being usually viviparous) after the same general plan as in the fertilised egg. That the cell from which these offspring developed was a true egg because it had undergone maturation was not, of course, known at that time.

There was much less ground for doubt regarding parthenogenesis in the rotifers and cladocera, because in these small transparent animals the eggs are conspicuous objects. Nevertheless, even in 1906, Punnett suggested that the rotifers might really be hermaphroditic, a possibility that has since been disproven by cytological studies.

External modifying factors.

The challenge to investigation of these cycles was their ever-recurring and sometimes apparently lawless change. Gamic forms were found to be abundant at certain times, wholly wanting at others. Winged aphids appeared in droves at certain periods, but only occasionally or not at all at other periods. Naturalists have habitually attributed striking or sudden changes of all sorts to environment. Temperature and nutrition were the obviously changing features of the environment, and they have been at one time or another held responsible for most of the alterations which these cycles undergo. 
Temperature and rotifers. The classic work of Maupas (189I) was the first to indicate experimentally an effect of temperature on the cycle of the rotifers. Rearing Hydatina senta at high temperatures, he obtained 97 per cent. of gamic forms, at low temperatures only 24 per cent. If the rotifers were alternated between these temperatures, more gamic females were produced at the high temperatures than at the low ones. Shull (I III) likewise obtained a temperature effect on this same species, but the relations were reversed; more gamic forms were produced at $10^{\circ} \mathrm{C}$. than at $20^{\circ} \mathrm{C}$. or $24^{\circ} \mathrm{C}$. Shull regarded this effect as an indirect one, altering the response of the animals to some other agent, and, as is pointed out below, Nussbaum ( 1897 ) conisidered Maupas's results to be due to starvation, since high temperature would cause the rotifers to multiply in their cultures, devour all their food, and thereafter starve. Hartmann (1919) included high temperature among the factors inducing periods of depression, and since depression is sometimes accompanied or followed by gamic reproduction, temperature might be said to be a factor in such reproduction. Other authors have been unable to find any effect of temperature, among them Nussbaum (1897), whose criticism of Maupas has been mentioned; Punnett (1906); Whitney (1907); Noyes (1922), working with a species (Proales decipiens) in which she never saw gamic individuals; and Watka (1928), who studied five different species. Certain workers have found that a change of temperature affects gamic reproduction. Thus Moro (I9I 5) concluded that either an increase or a decrease of temperature induces gamic forms; and according to Tauson ( $1926 a, 1927 b$ ), changes of temperature, while themselves ineffective, accentuate the response of the rotifers to changes of $p H$ (of which more is related below).

Temperature and cladocera. In the cladocera, Issakowitsch (1905, I907), Papanicolau (1910 $a, b$, I91 I), Grosvenor and Smith (1913), G. Smith (1915), and Banta and Brown (1924 $a, 1928)$ have concluded that low temperature induces gamic forms, while McClendon (1910) found contrariwise that high temperature has this effect. Some of these authors regarded the temperature as an indirect agent. Thus, according to Issakowitsch, and perhaps Grosvenor and Smith, the effect of low temperature is to reduce nutrition. G. Smith showed that fat is stored at low temperatures, glycogen at high temperatures, and that the gamic forms store chiefly fat; this he believed to be the manner in which low temperature favours gamic reproduction. A retardation of metabolism, accomplished by low temperature as well as certain other factors, was believed by Banta and Brown to be the primary agent. McClendon, who attributed gamic forms to high temperature rather than low, suggested that the permeability of the plasma membrane of the eggs is reduced so that they will not develop without the added stimulus of fertilisation, a suggestion that would have more point if the gamic egg and the parthenogenetic egg were identical up to the moment of possible fertilisation, which they are not, since, as is pointer out below, their maturation processes are different. As against all the preceding workers, there are two who were unable to observe any effect of temperature, namely, Kuttner (1909) and von Scharfenberg (1914), while Green (1919) was unable to interpret the results of his temperature experiments. 
Influence of temperature on aphids. In aphids, the effects of temperature, as of several other factors, are dual, since there are two phenomena to be influencedthe production of wings, and the stimulation of gamic reproduction. The gamic forms appear to have received the earliest attention. Kyber (1815) reared species of Siphonophora and Rhopalosiphum indoors for four years without any gamic forms, although these appeared out-of-doors in the same species at the appropriate season. Keller ( 1887 ) referred to Landois in 1867 as attributing the gamic generations to autumn conditions, but without specifying temperature in particular, and without indicating whether there was experimental evidence of such influence. Suggestions that temperature is one of the factors involved in gamic reproduction have been made by Hunter (1911), Baker and Turner (1916), Davidson (r921 $c$, $1927 a, b)$ and others, largely from the fact that low temperature prevails at the season when such reproduction occurs, and without any experimental evidence mentioned in the sources named, though Davidson (1924) definitely connected low temperatures with gamic forms of $A$ phis rumicis in experiments in which apparently no controls were maintained. Baker and Turner stated that more and more severe conditions (of which temperature is one) are required to bring on gamic forms in successive generations, but the evidence appears to be observations in nature. Klodnitski (I912) definitely held that temperature has no effect on mode' of reproduction, and stated that up to that time no other factor had been shown to have such effect. However, unpublished work of Shull on Macrosiphum solanifolii (= gei) shows an unmistakable effect upon the production oi gamic females. Winged mothers removed from low to high temperature produce gamic daughters at first, but gradually, over a period of ten days or two weeks, change completely to the production of parthenogenetic daughters, while similar females continued at low temperature yield almost exclusively gamic offspring. Many intermediates appear in the period of transition. The statement by Hottes (1928) that tropical species dispense with gamic forms may well find its foundation in this temperature effect.

The wings of aphids have been many times attributed at least partly to temperature. If suggestions based only on the observation of wings at times when certain temperatures prevailed be omitted, one of the earliest evidences of wing control by temperature was the work of Ewing (1916) on Aphis avenae, which showed the minimum of winged females produced at $65^{\circ} \mathrm{F}$., with larger numbers at both higher and lower temperatures, a result confirmed by Wadley (1923). Gregory (1917), however, believed that the temperature in Ewing's experiment acted indirectly by modifying the metabolism of the host plants. Wadley, also, regards the temperature as at least partly an indirect agent, since he found that $65^{\circ} \mathrm{F}$. interfered less with the wing-producing influence of starvation than other temperatures did. A similar suggestion of indirect action on nutrition in the plant appears in the paper of Mordwilko (1908). Call (1918) obtained many wings at $60-70^{\circ}$, none at $84-90^{\circ} \mathrm{F}$. And Ackerman (1926), after extensive experiments with Rhopalosiphum prunifoliae, concludes that maximum wing-production is attained at two temperatures ( $16^{\circ}$ and $24^{-2} 6^{\circ} \mathrm{C}$.), and minimum wing-production at two temperatures $\left(12^{\circ}\right.$ and $18-20^{\circ} \mathrm{C}$.). Ackerman also found that a change of temperature 
was followed, after 3-ro days, by maximum wing-production, after which, under constant temperature, wings gradually decreased in number. Finally, Shull (1929) shows temperature to act indirectly upon the effects of light. Alternating light and darkness, which produce wings under ordinary conditions, do so fully only at temperatures up to $20^{\circ}$, in diminishing degree from 20 to $24^{\circ} \mathrm{C}$, and not at all at $26^{\circ} \mathrm{C}$. and higher temperatures. The nature of this interference of high temperatures with the action of light and darkness is unknown.

Not all investigators, however, have found temperature a factor in wing-production. An old example is that of A. C.F. Morgan (1885), who argued that temperatures can have no such effect on Phylloxera, since wings are unknown in this form in Portugal-a suggestion made in evident expectation that high temperature, rather than low, might be expected to induce wings. Others finding no effect of temperature are Shinji (19.18), who experimented with chemical substances and stated that changes of temperature did not induce wings in his experiments with non-wing-developing substances; R. H. Smith (1923), who pointed out that winged individuals of the clover aphis appeared in August and September at temperatures as high as those of July; Marcovitch (1924), who believed that another factor (light) supplants the long-favoured temperature as a wing-producing agent; and Reinhard (1927), who obtained no wings in $A$ phis gossypii at any temperature from $70^{\circ}$ to $90^{\circ}$.

\section{Nutrition.}

Probably more attempts have been made to connect the life cycle of these animals with nutrition than with any other factor, temperature, however, being a close second.

Rotifers. The first experimental evidence of a nutritional effect on the cycle of rotifers appears to be that of Nussbaum (1897) who, on starving Hydatina senta, obtained an excess of gamic females. Since he got no such effect from low temperature, he suggested that Maupas's results from temperature were really dependent on nutrition, as explained above. Further experiments with starvation by Punnett (1906) and Whitney (1907) resulted in no change of the cycle. Shull $(1910 a, 1910 b)$ increased the number of gamic females from 25 per cent. to $3^{6}$ per cent. by starvation, but regarded this as due to the smaller amount of culture water (chemical substances) introduced with the smaller amount of food. More recently Tauson $(1927 b)$ concluded that low nutrition is the second most potent factor ( $p \mathrm{H}$ being first), and that combined with $p \mathrm{H}$ it may even increase gamic reproduction to 100 per cent. Opposed to the idea of starvation as a producer of the gamic females is the work of Mitchell (1913) on Asplanchna, in which it was found that low nutrition excluded the gamic forms, while high nutrition produced about 20 per cent. of gamic forms. He reported that starving very young females born of poorly nourished mothers made them all parthenogenetic; but that starving those derived from well-nourished parents made many of them gamic. Shull (1913 $b$ ) doubted the validity of these results because only ten individuals were used in each test, whereas rotifers exhibit sudden and extreme changes, under ordinary conditions, and because they implied an ability to change the females during their own 
lifetime, a point discussed further below. However, that high nutrition rather than low is the cause of gamic reproduction was supported by Whitney (1916), who stated that rich as against scanty food produced gamic forms in Brachionus and Pedalion; again by Whitney (1917a), using different kinds of food and several species of rotifers; again on Hydatina senta by Whitney (1919), when he pointed out that under certain conditions the food organisms become inactive and are less easily obtained by the rotifers; and by Wesenberg-Lund (1923), who called attention to what has probably been observed by all investigators of rotifers, namely, that abundant gamic reproduction is preceded by rapid increase in numbers of individuals.

No effect of starvation was obtained, however, by Zawadowsky (1916), according to Luntz, or by Noyes (I922) working on a species (Proales decipiens) in which the gamic forms were not known, or by Watka (1928) studying several species.

The study of nutrition was given a new direction by Whitney (1914 $a$ ), when he reported that the use of the green organism Chlamydomonas, instead of the usual colourless Polytoma, produced a great excess of gamic daughters. The test was repeated later on another strain (Whitney, 1915) with the same result, and still later (Whitney, 1916) with three genera of rotifers and, in part, another genus of green organism for food. Wesenberg-Lund (1923) reported finding under an algal carpet gamic forms of species not exhibiting these forms elsewhere, a fact easily interpreted as supporting Whitney's discoveries regarding green food. In all the experimental cases the green food yielded many more gamic females than did the colourless food. The effect was at first attributed to the quality of the green food as such, but it soon appeared (Whitney, $1914 b$ ) that mere change from Polytoma to Chlamydomonas was at least a large part of the cause. The idea that change of food, rather than a particular kind of food, favours gamic reproduction has been supported by Moro (1915); by Hodgkinson (1918), who reversed the change (from green to colourless food); by Luntz (1926), who worked with Pterodina elliptica and changed the food from Chlamydomonas to Polytoma or from Polytoma to Chlamydomonas with equal effect; and by Watka (1928), who obtained an increase of gamic reproduction in 60 per cent. of the experiments in which food was changed. Luntz stated that constant food, no matter which kind, yielded only parthenogenetic females, and that, if a change of food is to produce gamic forms it must be preceded by at least two successive generations with a single kind of food. He also found that change of food is effective only in a certain range of $p H$ values, a subject discussed later.

Nutrition in cladocera. From experiments with nutrition de Kerhervé (1892, I895) reported that abundant food caused continued parthenogenesis, while low nutrition induced males and gamic females. His experiments were apparently performed mostly with mass cultures. Issakowitsch (1905), with a few animals to each culture, found likewise that starvation or scant food tended to produce the gamic forms in the cladocera. Similar results with low temperature led him to conclude that the temperature reduced the nutritive processes or the supply of food, and that this was the immediate cause of gamic reproduction. He pictured the process 
as follows. If a female's nutrition is slightly lowered, she produces male offspring. If her nutrition is lowered still more, the oöcytes are unable to procure the requisite material for any kind of egg, with the result that they combine in groups to produce ephippial (gamic) eggs. If an empty ephippium was produced, the next brood was always parthenogenetic, which he interpreted to mean that the egg which should have been in the ephippium had been resorbed and served as food for the next oocytes, with the result that they were parthenogenetic. Keilhack (1906) objected to the idea of nutritive control of the cycle, on the ground that Polyphemus pediculus, which is dicyclic, passes through one of its gamic phases in June at a time when food is abundant. Strohl (1907) also, and for similar reasons, rejected the idea that gamic eggs result from low nutrition. Issakowitsch was supported, however, by Woltereck (1909), who based his conclusion on observations in nature ; by McClendon (rgro), who obtained confirmatory results from experiments; and by von Scharfenberg (I9I I), who reported, with respect to Daphnia magna, that much food results in parthenogenesis, less food in gamic reproduction, and no food in no change in the cycle. De la Vaulx (1919) obtained numerous intermediates, forms resembling both sexes in different features, at times of low nutrition, which might be interpreted to mean that a complete transition to the production of males could also be attained by low nutrition. Lack of food was listed by Hartmann (1919) as one of the factors inducing depressions, and these depressions are sometimes accompanied by gamic reproduction.

Certain authors besides Issakowitsch regarded the apparent effect of other agents as being produced through an effect on nutrition. Thus, Grosvenor and Smith (1913) held that low temperature and crowding may affect nutrition, though G. Smith (1915) was of the opinion that crowding affects accumulation of excretions, not a reduction of nutrition or the food supply. Apparently only one worker (von Scharfenberg, 1914) has reported a difference in the effect of different kinds of food. He was able to produce parthenogenetic or fertilised eggs at will in Daphnia magna by feeding with green algae, or with algae that had been eaten. and passed by other cladocera. Finally, Kuttner (1909) and Green (1919) obtained no effect on the cycle from differences in nutrition.

Nutrition in aphids. Relatively little evidence is available concerning nutrition as a factor in the gamic reproduction of aphids. Until these insects can be induced to feed on artificial media, it will continue to be impossible to alter their food without introducing other factors than simple nutrition. It is possible to withhold food altogether by removing the aphids from their plants, but no one appears to have influenced gamic reproduction by this procedure. Conclusions regarding the appearance of gamic forms as a response to nutrition must be therefore largely inferences even when the evidence is obtained from experiments. Nearly every writer who discusses this phase of the cycle mentions the probability or possibility that low nutrition does induce gamic reproduction. It is possible to interpret the 4-year parthenogenesis obtained by Kyber (1815), mentioned above, as due to high nutrition. Balbiani (1866) suggested nutrition as the controlling factor. Keller ( 1887 ) stated that Düsing in $188_{4}$ held nutrition responsible for the reproductive 
changes, and that Landois in 1867 attributed gamic forms to autumn conditions, of which reduced or altered food was no doubt conceived to be one. Davidson (1921 $b, 1921 c$ ) assents to the view that food conditions control gamic reproduction, and Hottes (1928) quotes Takahashi as finding only parthenogenetic aphids on young Celtis trees in Formosa, but some gamic forms on old trees.

On the whole, it can hardly be regarded as proven that nutrition has any such control, but this remark should not be interpreted to mean that it probably has not.

Much more information is available about the effect of nutrition upon wingproduction in aphids, although this evidence also suffers from confusion of what appears to be nutrition with things which may not be nutrition. Morgan (1885) found that Phylloxera on grape roots that were allowed to dry and die produced many winged individuals. Keller ( 1887 ) referred to the statement by Göldi in 1885 that starvation caused wing development in Pemphigus. Grassi (1907) is reported to have found that wings in Phylloxera depended partly on whether an American or a European variety of the host plant was used. Nutrition is one of the factors given by Mordwilko (1909) as inducing wings in his experiments, but he obtained wings sometimes so quickly that one is almost driven to conclude that the real factor started earlier in those cases. Woodworth (1908) observed that wilting of the plants was followed by wing-production. Crowding of the aphids was found to be followed by wing-production by Grassi (1907) in Phylloxera, Davidson (1914) in Aphis rumicis, Wadley (1923), Ackerman (1926) in Rhopalosiphim prunifoliae, and Reinhard (1927) in Aphis gossypii, though not by Slingerland (1893), while transfer of the aphids to young plants prevented wings, according to Klodnitski (I912). Experiments with starvation by Gregory (1917), Wadley (1923), Ackerman (1926), Reinhard (1927), and Shull (1928) showed this factor to induce wings, though in the work of Shull certain light conditions influenced the results, and in that of Ackerman and of Reinhard the number of winged individuals produced was greatly reduced, even to zero, if winged parents were starved. Indeed, Ackerman reports a decrease of wing-production when starvation of winged females was obtained by removal from the plant. Ackerman concluded, on the evidence as a whole, that abundance of water in the food, that is, dilute sap, favours wingless forms, while more concentrated sap favours wings. This conclusion agrees well with the less specific one of Davidson (1914) that a change of sap causes wingproduction, and with the observation by Davidson (1921 $a$ ) that deterioration of the plant brings on wings, and would explain why, on young plants, only wingless aphids should appear (Klodnitski, 1912).

\section{Chemical substances.}

The effect of substances in the medium is probably closely related to nutrition in a broad sense. It is particularly difficult to separate these agents in the case of aphids, where the substances must be administered to the host plant.

Chemical factors in the rotifer cycle. The earliest discovery of an effect of the chemical composition of the medium on the rotifer cycle was that of Shull ( 19 ro $a$, $\mathrm{I} \mathrm{g} \mathrm{IO} b$ ) who found that raising Hydatina senta in a fairly strong solution of horse 
manure, the liquid in which the rotifers' food was being reared, caused the gamic females to disappear. An attempt was made later to discover what parts of the manure solution had this effect, and it was found (Shull, I9II) that urea and the ammonium salts had such an effect, though not as marked. Other chemical substances reducing the number of gamic females were sodium hydroxide, butyric acid, cane sugar, beef extract, creatin, potassium sulphate, ferric chloride, and bouillon. All had the effect of suppressing gamic females, except very dilute calcium chloride (Shull, 1913a). That it was not merely the osmotic pressure of these solutions, not their acidity nor alkalinity, not merely their delay of physiological processes, that caused them to affect the cycle in like manner, was shown later by Shull and Ladoff (1916). In the meantime, Whitney (1910) discovered that a freshly made manure solution, if very dilute, increased gamic reproduction, and concluded that some transitory substance present in such a new culture must produce gamic females. In view of the work of Tauson $(1925,1926 a, 1927 b)$ and of Luntz (1926), soon to be described, it seems likely that the stimulating action of dilute fresh manure solution may be due, not to any particular substance in it, but merely to the change which it introduced. Similarly, the exceedingly dilute solutions of ferric chloride and other substances with which Moro (I9I5) induced gamic reproduction in Brachionus pala may act merely as changes in the environment, not as specific agents.

In the midst of the above discoveries, Whitney made known the effect of green food, already described, in stimulating the production of gamic females. Since oxygen is liberated by such organisms during photosynthesis, Shull and Ladoff (19r6) tested separately the effect of oxygen, and obtained an increase of gamic females, though not nearly so marked an increase as Whitney's Chlamydomonas produced. Oxygen was found particularly effective in counteracting such repressants as bouillon or manure solution. Later experiments by Shull ( $1918 a$ ) indicated that when Euglena is used as the green food, from one-fourth to one-third of its total effect in increasing gamic reproduction, which was a little more than enough to counteract strong manure solution, might be attributed to the oxygen liberated, the balance to the food as food. A second strain of rotifers showed a distinctly smaller effect of the oxygen.

Whitney was unable to find the effect of oxygen claimed by Shull. Fxtra oxygen, administered when Chlamydomonas was being used as food, he found (Whitney, I9I7 a) did not increase gamic reproduction, and he supposed that in Shull's experiments it had merely served to increase the protozoan food and thus increase gamic reproduction as a nutritive phenomenon. Whitney (1919) again concluded that oxygen was ineffective, since, with Chlamydomonas as food, fewer gamic: females were produced in the light than in darkness, and he suggested that light caused the Chlamydomonas to attach to the glass where they could not be devoured, and that lowered nutrition caused fewer gamic females to develop. Watka (1928) was also unable to get gamic females by use of oxygen. However, Tauson (1927 $b$ ) listed oxygen as the third most effective of all agents, not of itself, but through changes in its concentration. 
The recent work has dealt with $\mathrm{pH}$ of the medium and definitely known chemical content, with a refinement not approached in the earlier work. 'Tauson (1925), working with Asplanchna intermedia, showed that change of $p \mathrm{H}$ in either direction causes gamic reproduction, but that if the $p H$ is then kept constant at the new level, the effect gradually disappears. The $p H$ value he regarded as the most important of all external agents, and its effects are accentuated by temperature changes. Luntz (1926), working with Pterodina elliptica, got no effect of $p H$ by itself, but found that at certain levels it inhibits the effect of change of food.

With respect to salt content of the water, Tauson (I925) reported that increase of carbonate decreases gamic reproduction, and vice versa, and later (1927 $b$ ) listed the carbonates as the fourth most powerful of external agents. Their effect is largely in relation to $p H$ effects. Calcium has no effect by itself, but modifies the effect of $p \mathrm{H}$. Certain other substances appear to have no effect of any sort. According to Luntz (1926), changes in the salt content (standard Benecke solutions were used) within a certain range induced, by themselves, gamic reproduction, while in other ranges they modified the effects of change of food (described in a previous section).

All this work indicating that change, merely as change, stimulates gamic reproduction is quite in keeping with the results of change of food, and recalls such observations as those of Kahn (192I) who found that changing rotifers from one natural water to another brought on the gamic forms. However, not all investigators have obtained results with chemical substances. Mitchell (1913) and Noyes (I922) report negative results from such experiments.

Chemical substances and the cladocera. The first direct application of chemical substances to the modification of the cycle of the daphnids seems to have been made by Schmankewitsch (1875), when he changed Daphnia magna from weak to stronger salt solutions and obtained males and fertilised eggs. Acidity and alkalinity were tested by Papanicolau ( $1910 b$ ) without result. The next direct test was made by Green (I919) who applied sodium chloride to Simocephalus vetulus, without, however, obtaining any increase in gamic reproduction. Banta and Brown (1924 $a$, $1924 b$ ) successfully employed chloretone, uric acid, and carbon dioxide to induce the production of males, and alcohol and adrenal cortex to suppress gamic forms. 'These appear to be the only substances directly used to control the cycle.

Supposed chemical changes have been obtained, however, in other ways. Kurz ( 1874 ) stated that he was able to produce intermediate forms of Daphnia pulex at will by evaporating the water they were in down to one-sixth or one-eighth of its original volume, by which time both sexes were always present. Green (1919) made a similar attempt, but without success. Crowding the daphnids, or allowing them to remain long in the same water, resulting presumably in an accumulation of their excretions, has been repeatedly shown to induce gamic reproduction. Langhans ( 1909 ) pointed out that these excretions reduce growth and reproduction, and since gamic forms appear at times of maximum numbers, the two phenomena probably stand in relation of cause and effect. Hastening of gamic reproduction by excretions was observed by McClendon (1910), Grosvenor and Smith (1913), G. Smith (1915) who stated that the effect of crowding is on the excretions, not 
on the food, de la Vaulx (1922), and Banta and Brown (1923, 1924 $a, 1924 b, 1928)$. Quite consonant with these results is the statement of Langhans (1909) that removal of the animals repeatedly to clean water prolongs parthenogenesis indefinitely. A similar view regarding clean water was expressed by Papanicolau (1910 $a$ ), but later $(1910 b)$ he stated that excretions have not been shown to reduce anything but numbers. Hartmann (1919) included excretions as one of the factors causing depressions, which in his opinion makes them a probable cause of gamic reproduction. One race of Daphnia pulex, in the experiments of Banta ( $1925 b$ ), reacted peculiarly to crowding, in that ephippia were produced, the eggs in which were, however, parthenogenetic, and that no males resulted from crowding in this race. Crowding is not always necessary to obtain gamic forms, however, for Agar (1914) changed the water frequently, and permitted no crowding, yet obtained males; moreover, these males would appear in the first broods of the families.

The nature of the excretions has been seldom discussed. Banta and Brown (1923) stated that one experiment suggested carbon dioxide (and depletion of oxygen), but it is likely that other substances are in the minds of most investigators. How the excretions work has been considered by several authors. Thus, G. Smith (1915) pointed out that, under crowding, the animals store fat, rather than glycogen, and that fat is characteristic of the males and gamic females. According to Banta and Brown $(1924 a, 1924 b)$, substances which increase the rate of metabolism (alcohol, adrenal cortex) favour parthenogenesis, but that anything which reduces metabolism (crowding, carbon dioxide, uric acid, chloretone) may be expected to produce males. These males, however, have a higher rate of metabolism than the females, as in so many other animals; and the sexes respond to the Manoilov test (Banta and Satina, r925) in the same manner as in strictly bisexual species.

Chemical substances and the wings of aphids. The work done on aphids by means of chemical substances all relates to wing-production, none to gamic reproduction. Clarke (1903) is said to have obtained many more wings in the rose aphid if it was reared on cuttings kept in sand moistened with strong solutions of magnesium chloride or sulphate than with solutions of potassium or sodium salts or distilled water. Neiils (1912) confirmed Clarke's results on the same species, though the numbers involved were small. Shinji (1918), using also the rose aphid, reported many winged individuals on cuttings treated with salts of the heavy metals or magnesium, or with sugar, and practically no wings with a number of other substances. Wadley (1923) obtained very small, perhaps not significant, increases in wing-production with various salts, and dismissed them as not important in nature, anyway. However, Mason (1922, 1923), using Macrosiphum davisi, found no effect of magnesium sulphate, and Haviland (1921), working with Myzus ribis, obtained fewer winged forms with magnesium sulphate than with tap water (which, unfortunately, was not analysed). Ackerman (1926) was also unable to obtain excess of wings by any of the chemical treatments employed.

In view of these highly contradictory results, it must be said that an effect of chemical substances has hardly been proven. This is the more likely since such substances must be administered, not directly, but through plants. Protoplasm is 
highly selective in its absorption of salts, and some of the concentrations used in the experiments almost certainly killed it. No one has analysed any of the plants treated, to ascertain what, if any, change has been effected in them. Moreover, there are obviously so many factors affecting wings of aphids that the exclusion of all of them except the supposed chemical difference in any experiment involving a living plant seems rather unlikely. Indeed, the chemical difference may-even must-have produced other differences which may not have been chemical at all (differences in nutrition, for example).

\section{Light.}

With two exceptions, Watka (1928) who experimented with rotifers without result and Hartmann (192I) who found strong light a factor in the depression periods of cladocera, all of the work with light in the three groups with which we deal has been done on aphids. Light was long considered an indirect agent, affecting the growth of the host plant and hence the nutrition of the aphids (Mordwilko, I908). Probably the first suggestion that light might be a direct factor was made by Hunter ( $191 \mathrm{I}$ ) who was studying the gamic forms in Toxoptera graminum, but the suggestion was only a statement of a programme for the future which seems not to have been carried out.

To Marcovitch (1923, I924) belongs the credit of the discovery that light is an important factor in the cycle of the aphids. His conclusion was that a shortened day induced gamic reproduction and wings. Not all species acted in this way, however, and controls were lacking in some of the important experiments. Shull (1926, 1928) carried the work further with Macrosiphum solanifolii, with the following results. Wingless aphids reared in continuous light or continuous darkness produce almost all wingless offspring; but if the parents are alternated between light and darkness of certain durations, their offspring are nearly all winged. The effect of the light and darkness was proven to be directly on the aphids, not on their host plants. Removal from the plants for a certain length of time daily during light produced a moderate proportion of winged offspring, while removal from the plant during darkness had no such effect. In later work by Shull (1929)'it has been shown that, for the shorter durations of light, the longer the light lasts and the more intense it is, the more winged offspring are produced. The maximum effect of alternating light and darkness was obtained by about 6 hours of light and 12-14 hours of darkness. The effect was gradually diminished if the period of light were made more or less than 6 hours and if the darkness were made more than 14 hours long; but the effect was very suddenly reduced if the periods of darkness were made less than 12 hours. The most sharply defined time element was this requirement that darkness should last at least 12 hours. Alternating light and darkness in various time ratios proved effective, with only small differences, provided the dark periods were 12 hours long.

The effects described were produced at temperatures up to $20^{\circ} \mathrm{C}$., but rapidly disappeared at higher temperatures, until at $26^{\circ} \mathrm{C}$. alternating light and darkness did not produce wings at all. 
To explain these results Shull postulates a substance produced, perhaps photochemically, in the light, and converted into something else in darkness. The concentration of this latter something determines, he supposes, whether wings shall be produced.

\section{Physiological mechanism of response.}

The fundamental aim of the study of these cycles is discovery of the physiological processes involved in them. While knowledge of these processes has scarcely begun to exist, it is possible to point out the things most necessary to explain or most fruitful of evidence, the way of approach, and the steps already attempted along that road.

Time of action of external agent. One of the chief clues to the ultimate physiology of the cycles will no doubt be the time in the life of the individual in which critical events occur. With respect to the cladocera there is fair agreement. Woltereck (I9II) concluded that whether an egg was to become a male or an ephippial egg was decided either just before it leaves the ovary, or at three much earlier times. Green (1919) and Banta and Brown (1923, 1924 $b, 1928)$ limited the decision to one particular time, which the former stated to be before the egg leaves the ovary, the latter about four hours before the egg is laid. The latter statement is based on the fact that crowding is followed within four hours by the first males. In view of the difficulties of ascertaining more remote times, it seems likely that Woltereck's three earlier times may not exist, although the possibility of other susceptible periods must not be overlooked. Within the last few hours before it is laid, the egg undergoes its maturation division or divisions, which makes this seem an especially probable labile period.

In the rotifers, Shull (1912) showed that whether an egg becomes a gamic or a parthenogenetic female is decided within three hours before the egg is laid. Manure solution or bouillon of a concentration which completely excluded gamic females, was ineffective on eggs before they reached their final growth stage or after they were laid. The three hours before laying includes, as in the cladocera, the maturation process. Confirmatory conclusions were reached by Mitchell (1913) who stated that high nutrition must be applied to the mothers to induce gamic daughters in Asplanchna, by Moro (1915) whose chemical treatments of Brachionus pala were effective only on young individuals not yet born, and by Luntz (1926) who found that change of food just after one egg is laid causes the next egg of Pterodina elliptica to become a gamic female. Mitchell, however, concluded that starvation is also a factor in producing gamic females, and that it works on the oöcytes of the young female, to determine whether the oöcytes shall become gamic eggs. As pointed out above, and by Shull (1913 $b$ ), the ten individuals used by Mitchell in his tests seem scant evidence in an animal whose cyclical phenomena are as erratic as those of the rotifers. Hence it is not unreasonable to doubt the validity of Mitchell's latter conclusion. Storch, in his paper of 1923 , implied that treatment of a young female might cause it to become gamic, by suggesting that anything which causes the chromosomes to enter synapsis (as they do in young gamic, but not in parthenogenetic females) would cause that individual to become 
gamic. Apparently this suggestion is not repeated in his later paper (Storch, 1924). On the whole there seems to be as yet no necessity of supposing that there is any other labile period in the rotifers except that of the maturation of the egg.

In the aphids, the only evidence regarding the time of determination of gamic forms is the work of Shull mentioned above among the effecis of temperature. If winged females are changed from low to high temperature, they change from a progeny consisting almost wholly of gamic females to one of almost all parthenogenetic females, in a period of Io days to 2 weeks. The change is not a sudden, sharply defined one as in the rotifers, however, but is gradual, and intermediates are scattered along the latter third of this period. No calculation has yet been made of the stage which an aphid egg has reached two weeks before the offspring developing from it is born.

Concerning the determination of aphid wings there is little agreement. Neiils (1912) and Shinji (1918) using chemical substances, and Wadley (1923) using temperature and crowding, all concluded that wings may be determined in the lifetime of the individual-Neiils within 3 days after birth, Shinji 2-3 days after birth in one species and 5-7 days after birth in another species, and Wadley before the second moult-though there is room to conclude from Wadley's statements that starvation or crowding also worked on the parents to make the offspring winged. Shull (1928), on the contrary, showed that the whole effect of light on wing-production occurs within the last two days before birth. Moreover, as is pointed out more specifically below, there is a very strong tendency for winged parents to produce wingless offspring, even when the conditions are such that wingless parents produce many winged offspring. It must therefore be concluded that there is a very potent wing factor regularly acting before birth.

A common basis of environmental action. It is interesting, perhaps important, to note how many of the external agents which modify the cycles of these animals are effective only when they constitute a change from some previous condition. Thus, according to Luntz (1926), it is change of concentration of substances in the water, change of food, that induces gamic reproduction in rotifers. Tauson (1927 $b$ ) showed that change of $p \mathrm{H}$, change of oxygen, and change of temperature cause gamic females to appear in the same group. Shull (1928) found that change of light and darkness induces wings in aphids, while Ackerman (1926) concludes that the effect of a change of temperature on the wings of aphids soon disappears under constant temperature. Whitney (1924) calls his use of Chlamydomonas a sudden change from Polytoma as food, and his conclusion (Whitney, 1910) that there is a transitory substance present in new dilute manure cultures which induces gamic females suggests that mere change was the real factor. Not improbably many of the other factors which have been found to modify the various cycles do so merely because they are changes from previous conditions. In experiments lasting only a short time, as many of those reported necessarily did owing to the short life of the animals employed, the gradual disappearance of an effect under the constant conditions following a change would not be witnessed. Not all environmental effects can be interpreted as due to change, but the number which could be is greater than 
appears on the face of the evidence. Too little is known of the general physiological effects of a changing environment to pursue this matter further and suggest a fundamental explanation, but the subject offers an engaging clue for the future.

The physiological mechanism. Little is actually known of the intimate manner in which the protoplasm of these animals responds to environmental treatment. This section must therefore be either short or speculative. Issakowitsch (1905) devised a very simple scheme to account for the production of males by cladocera under reduced nutrition. It was simply that the available nutrition could not produce eggs of the size necessary to become females, hence males were produced. His explanation of the production of ephippial eggs upon still further reduction of nutrition did not include physiological details. McClendon (1910) suggested that the agents favouring ephippial eggs did so by reducing the permeability of the plasma membrane of the eggs, thus causing them to require the additional stimulus of fertilisation. Banta and Brown ( $1924 a, 1924 b, 1928$ ), as has been stated above, held that decrease in the rate of metabolism induces the production of males. In rotifers, Storch $(1923,1924)$ observed certain highly refractive bodies situated at the nuclear membrane of oöcytes in the gamic but not in parthenogenetic females. What physiological processes they might signify can only be conjectured.

The most highly evolved physiological conception relating to any of these cycles is that of Ackerman (1926) applied to wing-production in aphids. The haemolymph of the aphids contains numerous globules of presumably a lipoid substance. This substance differs physically, depending on the temperature at which the aphids are raised, so that in aphids raised at $28^{\circ} \mathrm{C}$. these globules solidify at about $9^{\circ} \mathrm{C}$., while in aphids raised at $12^{\circ} \mathrm{C}$. the globules solidify at about $-2^{\circ} \mathrm{C}$. Between these extremes there is a graduated series. In winged aphids, he found the solidification temperature of the globules to be always $1^{\circ}-3^{\circ} \mathrm{C}$. lower than in wingless aphids reared at the same temperature. When aphids were changed from one temperature to another, it required more than 14 days for the solidification temperature to drop to the degree characteristic of the new temperature. However, if the aphids were crowded, the solidification temperature changed about twice as fast as when they were not crowded. Young aphids born at a new temperature changed their lipoid-solidification temperatures more rapidly than their parents did. These effects appeared to be on the aphids directly, not indirectly through the plants. This evidence is circumstantial, but Ackerman believed it indicated some important relation between lipoid solidification and wing production, both, perhaps, being results of one cause.

Besides the colourless lipoid globules, the aphid used by Ackerman possesses some brown globules which, when treated with an alkali, become red. During the early stages of wing development, the haemolymph in the region of the wing buds is often purplish and, on treatment with alkali, becomes red. Ackerman concludes from these facts that the brown globules are disrupted during wing development, and their contents dissolved in the haemolymph. Certain microchemical tests indicated that some of the material was absorbed by the large lipoid globules, and it was found that the solidification point of the latter was thereby raised. Moreover, 
lowering the temperature of an aphid was found to cause the disruption of all the brown globules. Add to this that adult winged aphids immersed in sodium hydroxide became much less red than did adult wingless ones so immersed, demonstrating a smaller quantity of the responsible substance in the winged aphids, and the connection between the brown globules and wing-production is circumstantially fairly complete.

Ackerman's theory is that the brown globules are disrupted by mechanical disturbances, or temperature, or perhaps chemical disturbances, and that their substance is dissolved in the haemolymph and its contained lipoid globules, causing changes in the solidification temperature of the latter. Some part of this series of events, he supposed, stimulates the development of wings. The theory appears to him to explain the effect of external conditions, why these external conditions affect winged aphids much less than wingless ones, and why winged aphids have a much smaller tendency to produce winged offspring than wingless aphids have.

\section{Internal factors.}

Though it is rarely possible to separate internal factors completely from external ones, there are some features of the cycle in these groups which are relatively independent of the environment.

Age of parent. Shull (1910 a) found for the rotifer Hydatina senta that gamic females appeared distinctly more often in the middle of their mothers' families than at either the beginning or the end. Luntz (1926), however, reported for Pterodina elliptica that the response to external factors was the same at all ages. For the aphid Pemphigus spirothecae Mordwilko (1907 a) stated that the first eggs are large and produce females, the later ones are small and produce males. In the cladocera, Papanicolau (1910 a) found that the early broods of females had a strong tendency to be parthenogenetic females, the late ones gamic forms, while the middle ones were more balanced and easily turned one way or the other by external agents. More recent workers appear not to confirm this conclusion of Papanicolau, or attribute it to a changing environment.

Form of parent. In aphids it has been repeatedly observed that winged parents have a much smaller tendency to produce winged offspring than wingless parents have (Klodnitski, I912; Gregory, 1917; Shull, 1918 $b$; Davidson, I921 $c$; Mason, 1922, 1923; Wadley, r923; Ackerman, 1926; Reinhard, 1927). Almost an alternation of the winged type in one generation with wingless in the next, and so on, was reported by Mason, as a result of this factor. Also, Ackerman and Reinhard show that such wing-producing factors as crowding and starvation have a much smaller effect on winged parents than on wingless ones. According to Ackerman's theory, described above, the difference is due to a smaller amount of the substance contained in the brown globules (in his species) in the winged forms. Ewing (1926) assented to the general conclusion that wingless mothers tend to produce winged offspring, and earlier (Ewing, 1925) suggested that the effect is cumulative, since the tendency to produce winged offspring was greater after many successive generations of wingless ancestors. 'The latter suggestion seems now to be highly improbable. 
In many, perhaps most, aphid species there is a strong tendency, when the gamic forms are produced, for females and males to be born of different types of parent. Usually the male is produced by a wingless mother, the female by a winged mother. Perhaps there is the same relation here as that stated above, that winged parents have a strong tendency to produce wingless offspring, and vice versa, since males are usually winged and gamic females wingless, though wings cannot be the only thing involved in their production. However, there are variations in different species, for Klodnitski (I9I2), in a criticism of Balbiani, states that both gamic females and males may come from one mother, and Baker and Turner (1916) apparently believe this to be quite common.

An inherent cycle. Ever since Weismann's (r879) work on daphnians, and his conclusion that the different species are adapted to the bodies of water in which they live by entering upon the gamic phase of their cycle frequently or not, according as they are likely to be required to endure drought at frequent intervals or not, a controversy has waged over the possible existence of inherent cycles in the cladocera. Weismann's idea was that gamic forms appeared every so many generations, a different number in different species, and that the length of the cycle had been arrived at by natural selection. Support for this idea came later from Keilhack (1906), who saw in the dicyclic condition of Polyphemus pediculus a reminiscence of former arctic winters and an adaptation (by a repetition of the original cycle) to our milder modern seasons. Issakowitsch (1905) had concluded that there was no cycle in Weismann's sense, since he believed nutrition to be in control of gamic reproduction, but Keilhack argued that a gamic phase in June could not be due to lack of nutrition, a contention supported by Strohl (1907, 1908). Issakowitsch (1908) admitted that there must be a cycle in the sense that a gamic phase must be gone through, but insisted that the number of generations in it is determined by external conditions. Von Scharfenberg (1914) stated that in Daphnia pulex there is a strong tendency for gamic forms to appear in certain generations, which does not exist in Daphnia magna, and had earlier concluded (von Scharfenberg, r91 I) that the influence of food on the cycle is an inherited quality acquired through natural selection. Papanicolau ( 1910 a) regarded this latter idea as untenable, Agar (1914) said there is no certain number of generations in the cycle, and Banta (1914) concluded there is no inherent cycle; but van Herwerden (1918) accepted the innate cycle of Weismann.

If by cycles it is merely meant that different species or different strains respond in different degree to external conditions, by producing gamic forms earlier or later, or in greater or smaller numbers, probably most students of the cladocera now would admit that there are cycles. Woltereck (1909, 191 I, 1928) points out that this is true, and suggests an internal system of "paralysators" and "activators" which become latent by turns, and upon which environmental factors may work. McClendon (1910) recognised an inherited factor, and Banta (1914 et seq.), who has repeatedly pronounced against a cycle, must accept the existence of inherited differences.

A graduated cycle in the cladocera was proposed by Papanicolau (1910 a) who 
thought he saw plain evidence of an increasing gamic tendency from generation to generation. Agar (1914) mentioned a similar increasing tendency to produce gamic forms, but attributed it to the cumulative effect of environmental factors. Green (1919), on the contrary, found no such tendency in Simocephalus vetulus, and Banta (1925 a), after rearing 300 successive parthenogenetic generations of Moina macrocopa, found it was no easier then to call forth males by crowding than it had been in the early generations. Banta (1915) had also earlier shown that there was no progressive diminution of vigour after long-continued parthenogenesis, hence no inherent depression which Hartmann (1919) and others looked to as a cause of gamic reproduction.

An inherent cycle in the rotifers was assumed by Lauterborn (1898), who listed dicyclic and polycyclic species, and, though admitting the effects produced by temperature (Maupas, 1891) and by food (Nussbaum, 1897), concluded such effects could not be general. He regarded the cycle as regulated by internal factors, the gamic forms appearing in certain generations. Dieffenbach and Sachse (19II) also described species as monocyclic and dicyclic, and related the phenomenon to food, though whether physiologically or through natural selection is not wholly clear.

That strains differ from one another in their proportion of gamic forms under like conditions in the rotifer Hydatina senta was suggested by Punnett (1906) and shown by Shull (I9II) who crossed and back-crossed such lines and obtained different percentages of gamic females in each case. Similar differences were observed by Whitney (1912) in the same species, and by Luntz (1926) who worked with two strains of Pterodina elliptica, one of which produced 96 per cent., the other 50 per cent., of gamic offspring under the same external conditions.

A gradual decrease in the percentage of gamic forms from generation to generation was observed by Whitney (1912) and by Shull (1912). The latter described the phenomenon as a result of long-continued parthenogenesis, without, however, intending to imply exactly that this mode of reproduction was responsible for the decline. His idea, as explained later (Shull, 1923), was that the decrease of gamic reproduction was due to long-continued undisturbed metabolism. Gamic reproduction, had it intervened, would have provided the disturbance necessary to increase the proportion of gamic forms in succeeding generations, though it is probable that such an increase would be found only in the lines derived from certain, not all, of the fertilised eggs. As it has turned out since, an even more effective disturbance of metabolism has been provided by change of food, change of chemistry of the medium, and change of temperature, as described in a previous section of this paper. Recent workers, employing these changes to induce gamic reproduction, have not observed its gradual decline through numerous parthenogenetic generations (Tauson, 1926 ; ; Luntz, 1926).

An inherent reproductive cycle, different in different species, was held to exist in aphids by Klodnitski (1912), who stated that up to that time there had been no proof of any modification of the cycle by external factors. Baker and Turner (1916) concluded that, after temperature, the most important factor in gamic reproduction in plant lice is the number of parthenogenetic generations that have elapsed since 
the fertilised egg. They state, however, that successive generations appear to require more and more severe conditions to bring forth gamic forms, which is a reversal of what would be expected on the theory of an inherent cycle. Davis (1909), on the contrary, proved that gamic forms in several species do not appear in any definite generation. A progressive increase in the tendency of wingless females to produce gamic daughters in Macrosiphum solanifolii was observed one autumn by Shull (1918 $b$ ). It is usual for wingless females to produce males, and he has not witnessed their production of gamic females in such numbers since. The reason for this exceptional parentage one season is unknown.

In the same year in which the above observation was made, but during the summer, Shull (1918 $b$ ) also obtained a gradual increase in the number of winged individuals through a number of generations. In view of recent work (Shull, 1928) it seems likely that this change was due to some progressive change in the natural light conditions then prevailing, and that no cycle of wing-production was indicated. Wadley (1923) found no evidence of different strains or inherent factors in wingdevelopment, but Davidson ( $1927 b$ ), unable to account for observed phenomena by environmental factors alone, assumes an intrinsic factor as well. Perhaps the strongest evidence of inherited differences in wing-production is found in unpublished experiments of Shull demonstrating very striking differences in the response of two strains of the same species, Macrosiphum solanifolii, to alternating light and darkness, the results of which are, however, still too meagre to discuss further.

Periodicity. The periodic recurrence of gamic forms at intervals, especially noted in the rotifers, is probably closely related to the problem of cycles, but is doubtfully included here as due to internal factors. It must have been observed by every student of rotifers who has worked with several species, that gamic females and hence males tend to occur in "epidemics." Lange (1913-1914) regarded this as due to an internal rhythm, to which external factors are secondary. Mitchell (1913) described periods of rapid multiplication, which nearly coincided with periods of gamic reproduction, and considered the former to be the cause of the latter. To Shull (19I3 $b$ ), however, the two events seemed rather to be two results of a single cause, a view which finds support in the work of Wesenberg-Lund (1923) who, after pointing out that increase of numbers precedes gamic reproduction, went on to show that maxima of numbers are sometimes passed through without the appearance of gamic forms. Such epidemics of gamic reproduction, if they occur at irregular intervals, could well be explained by occasional changes of food or the composition of the water. However, Shull (I9I5) observed in one strain a recurrence of gamic forms every four weeks, and in another strain every nine weeks, with considerable regularity. Luntz (1926), finding no evidence of such periodicity in Pterodina elliptica, concluded that Shull must have changed the water or something every four weeks. That can hardly be the explanation, since the water was purchased from a commercial concern in large enough quantities to last six months to a year, and the quality of one shipment was presumably uniform, while food cultures were changed every several days. Moreover, the occurrence of a 4 -week 
and a 9-week periodicity at the same time seems to preclude Luntz's explanation. It seems not impossible that gamic reproduction is commenced when a certain substance is present in a given concentration in the protoplasm, that this substance is exhausted in the production of the gamic forms, and that a repetition of gamic reproduction must await the re-accumulation of the required amount. Under changing conditions of food or chemistry of the medium, such re-accumulation may be supposed to proceed rapidly, and every generation might include many gamic forms; but under uniform conditions, it would presumably occur slowly. At the basis of this physiological process would no doubt be a genetic factor which would cause one line to require four weeks, another nine weeks, and so on, to reach the threshold of stimulation.

In aphids, Davidson (1924) concluded that there is a periodic rhythm of gamic reproduction, though an elastic one; and in cladocera such cyclical phenomena would be explained by Woltereck (I I I I ) by competing substances, of which now one, now the other would gain the upper hand.

Intermediates. The occurrence of individuals combining certain characteristics of two types or intermediate between them has often been reported for the cladocera and the aphids. In cladocera, they are mostly intermediates between males and females. Kurz (1874) described such forms for three species, and called them hermaphrodites. He was able to produce them at will by evaporating the water down to a fraction of its original volume. Intermediates are mentioned by Kuttner (1909), and are described in detail by de la Vaulx (1915a, $1915 b)$ who appends a list of the literature concerning them. Certain lines, no doubt originating from mutations, have produced many such forms in the work of Banta (1916 $a, 1916 b, 1916 c$, 1917, 1918). One line was of the species Simocephalus vetulus, and included individuals combining in every conceivable way the primary and secondary differences between the sexes, some being hermaphrodites in the sense that both eggs and spermatozoa were produced. This line has four times branched off normal lines, presumably by return mutations, during the time it has been reared. Several similar intermediate-producing strains have arisen in Daphnia longispina (Banta, 1918), but none in four other species. De la Vaulx (I921) recorded $35^{\circ}$ intermediates in a line of Daphnia atkinsoni, and showed that the tendency to produce them is hereditary.

Intermediates between gamic and parthenogenetic females have been described in Daphnia pulex by Banta (1925 $b$ ) under the name of pseudosexual females. These produce ephippia, the eggs in which develop parthenogenetically. All of these occurred in one line, and no males were produced in that line. Probably a similar interpretation can be put on the observation of Olafsson (1918) that ephippial eggs develop parthenogenetically in the cold waters of Spitzbergen (cited by Woltereck, 1928).

Intermediate aphids appear to be fairly common. Moritz (I 893) described a pupa with only folds of the skin for wing pads, and other intermediates between winged and wingless forms were mentioned by Mordwilko (1909) and by Baker and Turner (1916). Klodnitski (1912) attributed them to the checking of wing-development by fresh food, and a similar explanation might be offered for those observed 
by Turner and Baker (1915) who obtained them on young apple seedlings. More liquid food, such as would be secured from fresh young plants, was suggested by Ackerman (1926) as the cause of winged-wingless intermediates. Shull, in experiments not yet published, has obtained numerous intermediates in one strain, few in another of the same species, showing that there is also a genetic factor in their production. Intermediates between gamic and parthenogenetic female aphids were described by Hunter (1910), and have been artificially obtained in numbers by changing winged parthenogenetic females from low to high temperatures in unpublished work of Shull. Fatio (1876) is said to have observed a pupal Phylloxera laying gamic eggs which Baker and Turner (1916) thought must have been an intermediate, though all that appears to be shown is that it was paedogenetic. Others that were intermediate and paedogenetic were recorded by Ewing (1916). The laying of non-black eggs by virgin gamic females observed by Baker and Turner (1916) in the green apple aphis, and known to occur in other species, perhaps as a response to environmental conditions, may also be looked upon as intermediacy between gamic and parthenogenetic females, since the latter regularly deposit their reproductive products, while the former usually do not unless impregnated.

The occurrence of intermediates in these groups indicates that type-determination either is in a more or less fluid state, or that it consists of several events spread over a considerable time. No attempt appears to have been made to discover which of these possibilities is correct, as it would seem possible to do where artificial means of producing intermediates have been discovered. No one has reported intermediate rotifers, which probably means that the event which decides the difference between parthenogenetic and gamic females is a single sharply-defined one occurring in a very brief interval of time.

Kernplasmarelation. Applying Hertwig's idea that the volume of the nucleus relative to that of the cytoplasm is of importance in physiological processes, including sex determination, Issakowitsch (1907) sought to explain the cladoceran cycle by supposing that the ratio $K / P$ (that of volume of nucleus to volume of cytoplasm) rises in case of degeneration or under those conditions which bring on gamic reproduction, and that the change of this ratio is the cause of the cyclical change. He reiterated this conclusion a year later (Issakowitsch, 1908). Papanicolau (1910b) supported this claim by camera lucida drawings of intestinal cells from animals raised under different conditions. These drawings were later measured by Shull (1922) and in all cases but one showed differences of the kind which Papanicolau indicated, though one of the differences was small. The theory that relative nuclear volume is of importance in the cladoceran cycle was combated by Strohl (1907, 1908), von Scharfenberg (1911), and Woltereck (1911), but was championed by Hartmann (I919). The last-narned author, from an examination of animals collected in nature, concluded that low temperature and long-continued parthenogenesis increased the ratio $K / P$, and that chemical substances also altered the ratio. The evidence of change was presented in drawings, not measurements, hence the numerical value of the increase is unknown. Not only the ratio of nucleus to cyto- 
plasm, but that of nucleolus to nucleus, and of cell surface to nuclear volume, Hartmann regarded as significant for the cycle.

The only examination of the Kernplasmarelation of rotifers was made by Shull (1922) who was induced to test the question because of the superior features of the rotifer Hydatina senta for this purpose. It had been shown that chemical substances could exclude gamic females in this species, that gamic females occurred in epidemics in certain strains, and that more gamic females were produced in the middle of a family than near either end. Three independent ways of testing the nucleoplasma ratio were therefore available, and if that ratio were a causal agent it should undergo corresponding changes in all three circumstances. If it were merely incidental, it might coincide with expectation in one or more cases, but not in the others; or it might not fit the expectations at all. Shull examined the intestine, yolk gland and the oocytes, and though changes were found to take place in the $K / P$ of some of them under some conditions, none of them was what would have been expected on the theory. In Hydatina senta, therefore, the Kernplasmarelation appears to have nothing to do with the cycle of reproduction.

\section{Chromosomes and maturation.}

There is general agreement now that in all three groups with which we deal the parthenogenetic eggs undergo only one division in maturation, while the gamic eggs divide twice, and that reduction of the chromosomes occurs in the latter, not in the former. Concerning the chromosome numbers, some details of maturation, and maturation in the male there are differences of opinion and differences in species.

In the rotifer Hydatina senta Lenssen (1898 $a, 1898 b$ ) found the diploid number of chromosomes to be 10 or 12 , the two numbers probably representing uncertainty of count, not a difference between individuals, while 5 chromosomes were found in the mature gamic eggs. Whitney (1909), upon admittedly uncertain counts, thought the diploid number was 20-30, the haploid number in the gamic eggs I I-14, while Shull (1921) definitely concluded that the parthenogenetic egg received 12 chromosomes, the gamic egg 6, when mature. In Asplanchna priodonta, Storch (1923, 1924) observed synapsis, and the omission of a resting stage following the last oögonial division, in gamic females but not in parthenogenetic ones. Eight tetrads are formed, and two divisions occur in the gamic eggs, and 8 chromosomes are present at the end of maturation. In the mature parthenogenetic egg there are 16 chromosomes. Lehmensick (1926), in a study devoted mostly to other features, found 14-16 chromosomes in cleavage in this species. In Asplanchna intermedia there is an important difference of opinion. Tauson (1924) found 24 chromosomes in the parthenogenetic egg, 12 in the gamic egg, when mature; while Whitney (1924) counted 52 and 26 chromosomes respectively. Tauson, however, counted the diploid number (24) in the cleavage stages of the unfertilised gamic egg, so that the male possesses 24 chromosomes like the female. A doubling of the chromosomes must occur at an early cleavage stage of the male, or before. In Asplanchna amphora, according to Whitney (1929), there are 26 chromosomes in the mature parthenogenetic egg and the somatic cells of the embryo derived from 
it. The chromosomes are larger in some such embryos than in others, and Whitney suggests the possibility that these two kinds are the parthenogenetic and gamic type of female. It is known, as shown in an earlier section, that at least in some rotifers the two kinds of female are already determined at a stage earlier than cleavage. Whitney found that the number of chromosomes in the mature gamic egg of this species is I 3 , and the same number occurs in the somatic cells of the embryo (the male) derived from an unfertilised gamic egg. In Brachionus pala, 10 chromosomes were counted (Marinelli, 1925) in mature parthenogenetic eggs; and while the reduced number was not actually counted in the gamic eggs, Marinelli conceded that in general male rotifers are haploid.

Spermatogenesis in rotifers has been carefully studied by only two investigators. Whitney ( $1917 b$, I9I8) had found that males of II species produce spermatozoa of two kinds: active functional ones, and smaller, rudimentary, motionless ones. In Asplanchna intermedia he concluded later (Whitney, 1924) that the primary spermatocytes, containing as he believed 26 chromosomes, do not usually divide into secondary spermatocytes, but transform directly into spermatozoa, which therefore have 26 chromosomes. Some of the primary spermatocytes, however, divide, each daughter cell receiving I 3 chromosomes, and these cells he holds become the rudimentary spermatozoa. Tauson (1927 $a$ ), however, gave the following account of spermatogenesis in Asplanchna intermedia. Starting with 24 chromosomes, which according to Tauson is the diploid number for this species, the number is reduced to $\mathrm{I} 2$ in early spermatogonial divisions. There is only one maturation division, each cell receiving 12 chromosomes. These secondary spermatocytes are transformed directly into spermatozoa, all of which are functional. The account of spermatogenesis in Asplanchna amphora given by Whitney (1929) agrees with that of Tauson for $A$. intermedia in that only one division regularly occurs, the secondary spermatocytes receiving 13 chromosomes and becoming spermatozoa. Some secondary spermatocytes divide, however, each spermatid receiving fewer than 13 chromosomes. These spermatids, according to Whitney, become the rudimentary, non-motile spermatozoa.

The accounts of spermatogenesis in the rotifers are thus sufficiently contradictory in important respects, and so remarkable as compared with normal spermatogenesis, that it seems necessary to withhold a definite opinion regarding them until further critical examination of them is made.

Less has been done with the chromosomes of the cladocera. Kühn (1908) observed only one division and no reduction in the parthenogenetic eggs of Daphnia pulex and Polyphemus pediculus. The number of chromosomes was found to be probably 8. Schrader (1925) studied cytologically the pseudosexual or intermediate race of Daphnia pulex which Banta $(1925 b)$ discovered, and counted 24 chromosomes, and observed only one division, precisely as in the normal parthenogenetic egg.

Spermatogenesis in Simocephalus vetulus was found by Chambers (1913) to involve two divisions, and a reduction of the chromosomes to 8 from a much larger undetermined number. About half of the spermatids were said to degenerate. 
There was no observable difference between the degenerating and normal ones. In Daphnia pulex, Taylor (1914) counted 8-10 chromosomes in the spermatogonia, observed a well-marked synizesis in the spermatocytes, saw two divisions, and found 4 or 5 chromosomes in the spermatids. None of the spermatids appeared to degenerate. The male with its original 8-10 chromosomes thus appears to be diploid. In agreement with this evidence of diploidy in the males is the genetic evidence advanced by Banta and Wood (1928), who crossed a mutant short-beaked male with a normal wild-type female, and obtained some short-beaked and some normal wild-type offspring in every progeny. It would be possible, however, to explain this divided progeny by irregular dominance.

Of the aphids, Aphis rosae appears to be the first for which chromosome counts were made. Stschelkanovzew (1904) observed only one division in the maturation of the parthenogenetic egg, saw no early splitting of the chromosomes (which presumably has reference to synapsis), and counted 14 chromosomes. The number was changed to ro for this species by Stevens (1905), Hewitt (1906), and von Baehr (1909), Hewitt suggesting that Stschelkanovzew counted cut chromosomes. Stevens showed further that these Io chromosomes are of five different sizes, and that in the gamic egg, whose maturation involves two divisions, the final 5 chromosomes are of the same five sizes. In the parthenogenetic eggs, she at first saw no difference. between those that were to develop into males and those that would become females. T.H.Morgan (1908, 1909), however, demonstrated a decrease of the number of chromosomes in the male-producing egg of Phylloxera fallax from 12 to 10, through the elimination of two whole chromosomes into the polar body; and von Baehr (1908, 1909) found a decrease from 6 to 5 in the male-producing egg of Aphis saliceti by a similar elimination of one undivided chromosome. Numbers of chromosomes in other species of aphids were reported by von Baehr as follows: in Schizoneura lanigera, 12; and in Pemphigus pyriformis, 20.

The spermatogenesis of the aphids is illustrated by that of Phylloxera fallax (T.H. Morgan, I908, 1909), in which the female has 12 chromosomes, the male Io. Eight of the ro chromosomes pair, and separate at the first division, the other two going undivided to one pole. One cell thus receives 6 chromosomes, the other only 4 ; the former cell is much larger than the latter. The large cell divides into spermatids with 6 chromosomes each, while the small cell does not divide, but degenerates. A similar process occurs in Aphis saliceti according to von Baehr (1908, 1909), in which the female has 6 , the male 5 chromosomes. The large cell produced by the first division in the male receives 3 chromosomes, and divides again into spermatids of 3 chromosomes each. The small cell resulting from the first division does not divide again, though it sometimes starts to do so before degenerating. As is pointed out below the functional spermatozoa are all femaleproducing.

\section{Sex determination.}

The expression "sex determination" is not here intended to be applied to the introduction of gamic forms, although the name has often been given to that 
phenomenon. Nor will any defence of the practice of calling the production of males and gamic females by the name "sex determination" be made, except to point out that it is more or less justified in the rotifers where the only way to obtain males is first to produce a gamic female, which is not true of the other groups. Determination of a gamic female rotifer is the last possible step in the determination of males, except one, namely, the prevention of fertilisation of her eggs. What is referred to as sex determination in this section is the final event which determines sex in any case.

In all three groups, fertilisation of a gamic egg is one such final event. All fertilised eggs. of rotifers, aphids and cladocera become females. By analogy with other animals, it was to be expected that all functional spermatozoa would be found to be of the female-producing type. What evidence there is is mostly in support of this expectation, or is at least readily interpretable as support. In the aphids, as shown by T. H. Morgan (1908, 1909) and von Baehr (1908, 1909), two kinds of spermatids are produced, of which one degenerates. From the chromosome content of these degenerating cells, it must be inferred that they are the male-producing ones. In the cladocera Chambers (1913) found half the spermatids degenerating, and though he saw no morphological differences between the degenerating cells and the functional ones, suggested that the former were probably male-determining. Taylor (1914), it will be recalled, saw no evidence of any degeneration, but this is hardly surprising in such difficult material. The degenerating spermatids of aphids were overlooked for a time by competent cytologists who were deliberately searching for X-chromosomes. It may be confidently predicted that, when cladoceran spermatogenesis is better known, a mechanism comparable with that of the aphids will be found. In rotifers, Whitney $(1917 b, 1918)$ discovered rudimentary spermatozoa making up about one-third of the total number. From this ratio he inferred that maturation in the male rotifer might consist of a first division in which unequal cells were produced, and a second division involving only the larger of the two cells. The small cell produced by the first division he assumed would have been of the male-producing type. The cytological evidence in its present state does not coincide exactly with this inference. In Asplanchna intermedia, according to Whitney (1924) as described above, the gamic egg has 26 chromosomes, the functional spermatozoa 26 , while the degenerate spermatids (what few of them are produced) have I3. If one of the latter should fertilise an egg, there would be 39 chromosomes in the zygote, and there might be some question as to the sex of the rotifer developing from it. If spermatogenesis is correctly outlined by Whitney, one must probably infer that the number of chromosomes in both gamic eggs and functional spermatozoa has been at some time doubled, and that it was formerly 13 . It is difficult, however, to find in the account of spermatogenesis in the same species by 'Tauson (1927 a) a ready parallelism with sex determination by two types of spermatozoa. It seems likely that there are still important discoveries to be made in the cytology of the rotifers.

Another important event which constitutes a final determination of sex occurs in the maturation of the parthenogenetic eggs of aphids and phylloxerans, as 
discovered by Morgan and von Baehr (see above). The elimination of entire chromosomes into the polar body, by a division in which all other chromosomes divide, results in an egg with a slightly smaller number of chromosomes than in an egg in whose maturation all chromosomes divide. The chromosomes whose behaviour differs in different oöcytes are undoubtedly the X-chromosomes. However, too much stress must not be laid on this chromosome behaviour as a sexdetermining process, since in the Phylloxera the eggs are small, and hence destined to become males, before the chromosomes are eliminated. Nothing comparable to this is known in the cladocera, since the male appears, from the available evidence, to have the same number of chromosomes as the female; and in the rotifers, the descent of the male from the gamic female throws responsibility for male determination back into the maturation of the egg from which the gamic female develops. What happens there is not known, but appears to have nothing to do with the number of chromosomes.

\section{BIBLIOGRAPHY.}

ACKERMAN, L. (1926). "The physiological basis of wing-production in the grain aphid." fourn. Exp. Zool. 44, 1-61.

AGAR, W. E. (1914). "Parthenogenetic and sexual reproduction in Simocephalus vetulus and other Cladocera." Yourn. Genet. 3, 179-194.

von BAeHr, W. B. (1908). "Uber die Bildung der Sexualzellen bei Aphididae." Zool. Anz. 33, 507-5I7.

_- (1909). "Die Ö̈genese bei einigen viviparen Aphididen und die Spermatogenese von Aphis saliceti, mit besonderer Berücksichtigung der Chromatinverhältnisse." Arch.f. Zellforsch. 3, 269-333.

Baker, A. C. and TURNer, W. F. (1916). "Morphology and biology of the green apple aphis." Journ. Agr. Res. 5, 955-993.

Balbiani, E. G. (1866). "Sur la reproduction et l'embryogénie des Pucerons." Comp. Rend. Acad. Sci. Paris, 62, 1231-1234, $1285-1289,1390-1394$.

BAntA, A. M. (1914). "One hundred parthenogenetic generations of Daphnia without sexual forms." Proc. Soc. Exp. Biol. Med. 11, 180-182.

- (1915). "The effects of long-continued parthenogenetic reproduction ( 127 generations) upon Daphnids." Science, 41, $44^{2}$.

- (1916 a). "Sex intergrades in a species of Crustacea." Proc. Nat. Acad. Sci. 2, 578-583.

— (1916 b). "A sex intergrade strain of Cladocera." Proc. Soc. Exp. Biol. Med. 14, 3-4.

_ (1916 c). "Sex intergrades in a species of Crustacea." Proc. Nat. Acad. Sci. 2, 578-583.

- (1917). "A strain of sex intergrades." Anat. Rec. 11 (6), I-2.

- (1918). "Sex and sex intergrades in Cladocera." Proc. Nat. Acad. Sci. 4, 373-379.

- $(1925 a)$. "The relation between previous sexual reproduction and the production of male offspring in Moina macrocopa." Am. Nat. 59, 50-6x.

- $(1925 b)$. "A thelytokous race of Cladocera in which pseudosexual reproduction occurs." Zeit. ind. Abst. Vererb. 40 (1, 2), 28-41.

Banta, A. M. and Brown, L. A. (1923). "Some data on control of sex in Cladocera." Eugenics, Genetics and the Family. Scientific Papers of the Second International Congress of Eugenics, 1, 142-149.

- (1924a). "Rate of metabolism and sex control in Cladocera." Anat. Rec. 29, 147.

- (1924 b). "Rate of metabolism and sex determination in Cladocera." Proc. Soc. Exp. Biol. Med. 22, 77-79.

_ - (1928). "Sex control in a daphnid.". Science, 68, 649.

Banta, A. M. and Satina, S. (1925). "A biochemical reaction associated with sex in Cladocera." Proc. Soc. Exp. Biol. Med. 22, 466-467.

Banta, A. M. and WOOD, Thelma R. (1928). "Inheritance in parthenogenesis and sexual reproduction in Cladocera." Int. Rev. d. ges. Hydrob. u. Hydrogr. 19, 264-269.

BurnetT, W. I. (1856). "Researches on the development of the viviparous Aphides." Proc. Am. Assoc. Adv. Sci. VII Meet. 1853, 203-223. 
Call, L. E. (1918). Kansas Agric. Exp. Sta. Director's report for 1917-1918, 20.

Chambers, R. (1913). "The spermatogenesis of a Daphnid, Simocephalus vetulus." Biol. Bull. 25, 134-140.

Clarke, W. T. (1903). "Conditions favoring wing development in N. rosae Linn." Journ. of Tech. Univ. of Calif. Stud. Pub. 1, 96-99.

Davidson, J. (1914). "The host plants and habits of Aphis rumicis Linn., with some observations on the migration of, and infestation of plants by aphides." Ann. Appl. Biol. 1, 118-141.

-_ (1921 a). "Biological studies of Aphis rumicis Linn. 1746." Ann. Appl. Biol. 8, $51-65$.

-_- (1921 b). "Biological studies of Aphis rumicis Linn." Bull. Ent. Res. 12, 81-89.

- ( $1921 \mathrm{c}$ ). " Biological studies of Aphis rumicis Linn. A. Appearance of winged forms. B. Appearance of sexual forms." Sci. Proc. R. Dublin Soc. 16, 304-322.

- (1924). "Factors which influence the appearance of the sexes in plant lice." Science, N.S. 59, 364 .

__ (1927 $a)$. "The biological and ecological aspect of migration in aphides. Part I." Science Progress, 21, 641-658.

_ $(1927 b)$. "On the biological and ecological aspect of migration in aphides. Part II." Science Progress, 22, 57-60.

Davis, J. J. (1909). "Biological studies on three species of Aphididae." U.S. Dept. Agric. Bur. Ent. Tech. Ser. 12, part 8.

Dieffenbach, H. and Sachse, R. (Igi I). "Biologische Untersuchungen an Rädertieren in Teichgewässern." Int. Rev. d. ges. Hydrob. u. Hydrogr. Biol. Suppl. 3, 1-93.

EwiNG, H. E. (1916). "Eighty-seven generations in a parthenogenetic pure line of Aphis avenae Fabr." Biol. Bull. 31, 53-112.

_ (1925). "The factors of inheritance and parentage as affecting the ratio of alate to apterous individuals in aphids." Am. Nat. 59, $311-326$.

- (1926). "Wing production in plant lice." Am. Nat. 60, 576-579.

Fatro (1876). "Le Phylloxera dans le canton de Genève d'aout 1875 à juillet 1876 ." Rapport au département de l'intérieur du canton de Genève.

Grassi, B. (1907). "Ricerche sulle filossere etc. esequite nel R. osservatorio antifilosserico di Fauglia etc." Rendiconti dell' Accad. d. Lincei, I Sett. 1907.

Green, W. R. (1919). "Studies in the life cycle of Simocephalus vetulus." Biol. Bull. 37, 49-95.

Gregory, L. H. (1917). "The effect of starvation on the wing-development of Microsiphum destructor." Biol. Bull. 33, 296-303.

Grosvenor, G. H. and Smith, G. (1913). "The life cycle of Moina rectirostris." Q.Y.M.S. 58, $511-522$.

Hartmann, O. (1919). "Uber das Verhalten der Zell-, Kern- und Nucleolengrösse und ihrer gegenseitigen Beziehungen bei Cladoceren während des Wachstums, des Generationszyklus und unter dem Einfluss äusserer Faktoren." Arch.f. Zellforsch. 15, I-94.

Haviland, M. D. (192I). "The experimental production of winged forms in an aphid, Myzus ribis Linn." Ann. Appl. Biol. 8, 101-104.

van Herwerden, M. A. (1918). "Untersuchungen über die parthenogenetische und geschlechtliche Fortpflanzung von Daphnia pulex." Verhandelingen der Koninklijke Wetenschappen, Amsterdam, and section, $20(3), 30 \mathrm{pp}$.

Hewrt, C. G. (1906). "The cytological aspect of parthenogenesis." Mem. Proc. Manchester Lit. Phil. Soc. $50(6), 1-38$.

HodGkinson, E. E. (1918). "Some experiments on the rotifer Hydatina." Yourn. Genet. 7, 187-192.

Hottes, F. C. (1928). "Borderline aphid studies." Proc. Biol. Soc. Wash. 41, 133-138.

HunTER, S. J. (1910). "On the transition from parthenogenesis to gamogenesis in aphids and braconids." Science, N.S. 31, 476.

- (IgII). "On the transition from parthenogenesis to gamogenesis in aphids." Science, N.S. 33, $267-268$.

Issakоw IтsCh, A. (1905). "Geschlechtsbestimmende Ursachen bei den Daphniden." Biol. Cent. 25, 529-536.

_ (1907). "Geschlechtsbestimmende Ursachen bei den Daphniden." Arch. mikr. Anat. Entto. $69,223-244$.

- (1908). "Es besteht eine zyklische Fortpflanzung bei den Cladoceren aber nicht im Sinne Weismanns." Biol. Cent. 28, 51-61.

K^нN, O. L. (1921). "Der Einfluss ausserer Faktoren auf die Bestimmung des Geschlechts bei Asplanchna." Mitt. d. Inst. f. exp. Biol. Moskau, 1.

Kerlhack, L. (1906). "Zur Biologie des Polyphemus pediculus." Zool. Anz. 30, 911-91 2.

KelleR, C. (1887). "Die Wirkung des Nahrungsentzuges auf Phylloxera vastatrix." Zool. Anz. 10, $583-588$.

DE KeRHeRvé (1892). "De l'apparition provoquée des éphippies chez les Daphnies (Daphnia magna)." Mém. Soc. Zuol. France, 5. 


\section{Determination of types of individuals in aphids, rotifers and cladocera}

DE KERHervé (1895). "De l'apparition provoquée des males chez les Daphnies." Mém. Soc. Zool. France, 8.

KLOdnITSKI, I. (IgI 2). "Beiträge zur Kenntnis des Generationswechsels bei einigen Aphididae." Zool. Jahrb. Abt. Syst. Geog. u. Biol. 33, 445-520.

KOHN, A. (1908). "Die Entwicklung der Keimzellen in den parthenogenetischen Generationen der Cladoceren Daphria pulex de Geer und Polyphemus pediculus de Geer." Arch.f. Zellforsch. 1, $53^{8-586 .}$

KuRz, W. (1874). "Uber androgyne Missbildung bei Cladoceren." Sitz.-ber. math. naturw. Akad. Wiss. Wien, 69, 40-46.

KUTTNER, O. (1909). "Untersuchungen über Fortpflanzungsverhältnisse und Vererbung bei Cladoceren." Int. Rev. d. ges. Hydrob. u. Hydrogr. 2, 633-607.

KYBER, J. F. (1815). "Einige Erfahrungen und Bemerkungen über Blattlăuse." Germar's Mag. der Ent. 1, 1-39.

LANGE, A. (1913-14). "Unsere gegenwärtige Kenntnis von den Fortpflanzungsverhältnissen der Rädertiere." Int. Rev. d. ges. Hydrob, u. Hydrogr. 6, 257-279, 429-452.

Langhans, V. H. (rgog). "Uber experimentelle Untersuchungen zu Fragen der Fortpflanzung, Variation und Vererbung bei Daphniden." Verh. deutsch. zool. Ges. 19, 281-291.

Lauterborn, R. (1898). "Uber die zyklische Fortpflanzung limnetischer Rotatorien." Biol. Cent. $18,173-183$.

LeHMENSick, R. (г 926). "Zur Biologie, Anatomie und Eireifung der Radertiere. Untersuchungen an Asplanchna priodonta, Euchlanis triquetra, Synchaeta pectinata und Polyarthra platyptera." Zeit.f. wiss. Zool. 128, 37-1 13.

LENSSEN, J. (1898a). "Contribution à l'étude du développement et de la maturation des œufs chez l'Hydatina senta." La Cellule, 14, 419-45I.

_- (1898b). "Contribution a l'étude du développement et de la maturation des œufs chez l'Hydatina senta." Zool. Anz. 21, 617-622.

LuNTZ, A. (I926). "Untersuchungen über den Generationswechsel der Rotatorien. I. Die Bedingungen des Generationswechsels." Biol. Zent. 46, 233-256, 257-278.

Marcovitch, S. (1923). "Plant lice and light exposure." Science, 58, 537-538.

- (1924). "The migration of the Aphididae and the appearance of the sexual forms as affected by the relative length of daily light exposure." fourn. Agric. Res. 27, 51 3-522.

MARINELL, W. (1925). "Untersuchungen über die Eizellen von Brachionus pala." Zeit. f. wiss. Zool. 125, $135-166$.

Mason, A. C. (1922, 1923). "Relation of environmental factors to wing development in aphids." Florida Entom. 6, 25-32; 7, $1-7$.

MaupAs, E. (r 89r). "Sur la déterminisme de la sexualité chez l'Hydatina senta." Comp. Rend. Acad. Sci. Paris, 113, 388-390.

MCClendon, J. F. (1910). "On the effect of external conditions on the reproduction of Daphria." Am. Nat. 44, 404-4II.

MitcheLl, C.W.(1913). "Sex determination in Asplanchna amphora." Yourn. Exp.Zool.15, 225-255.

Mordwilko, A. (1907 a). "Beitrăge zur Biologie der Pflanzenläuse, Aphididae Passerini." Biol. Cent. 27, 529-550, 561-575t

— (1907 b). "Beiträge zur Biologie der Pflanzenlăuse, Aphididae Passerini. Die zyklische Fortpflanzung der Pflanzenlause. II. Die Migrationen der Pflanzenlăuse, ihre Ursachen und ihre Entstehung." Biol. Cent. 27, 747-767, 769-816.

-_ (1908). "Beiträge zur Biologie der Pflanzenläuse, Aphididae Passerimi." Biol. Cent. 28, 631$639,649-662$.

— (1909). "Beitrăge zur Biologie der Pflanzenläuse, Aphididae Passerini. Die zyklische Fortpflanzung der Pflanzenlause." Biol. Cent. 29, 82-96, 97-118, 147-160, 164-182.

MORGAN, A.C. F. (1885). "Notes on experiments made with the winged form of Phylloxera vastatrix radicicola." Trans. Ent. Soc. London, Proc. 1885 , pp. xxvii-xxxii.

MORGAN, T. H. (1908). "The production of two kinds of spermatozoa in phylloxerans, functional 'female-producing' and rudimentary spermatozoa." Proc. Soc. Exp. Biol. Med. $\mathrm{B}$.

- (1909). "A biological and cytological study of sex determination in phylloxerans and aphids." fourn. Exp. Zool. 7, 239-353.

MorITz, F. (I 893). "Beobachtung und Versuche, betreffend die Reblaus Ph. vastatrix Pl. und deren Bekämpfung." Arbeit. a. d. Kais. Ges. 8, 532.

MoRo, L. (1915). "Partenogenesi e anfigonia nei Rotiferi. Ric. sperim. sul Brachiontus pala." Bios, 2, $219-264$.

NeIILS, J. D. (1912). "Wing production in aphids." Ent. News, 23, 149-151.

NOYES, BESSIE (1922). "Experimental studies on the life history of a rotifer reproducing parthenogenetically (Proales decipiens)." foum. Exp. Zool. 35, 225-255.

Nussbaum, M. (1897). "Die Entstehung des Geschlechts bei Hydatina senta." Arch. mikr. Anat. Entro. 49, 227-308. 
Olafsson, O. (1918). "Studien über die Süsswasserfauna Spitzbergens. Beitrag zur Systematik, Biologie und Tiergeographie der Crustaceen und Rotatorien." Zoologiska Bidrag, 6, 183646.

Papanicolau, G. (rgro a). "Uber die Bedingungen der sexuellen Differenzierung bei Daphniden." Biol. Cent. 30, 430-440.

- $(1910 b)$. "Experimentelle Untersuchungen über die Fortpflanzungsverhältnisse der Daphniden (Simocephalus vetulus und Moina rectirostris var. Lilljeborgii)." Bial. Cent. 30, 689-692, $737-750,752-774,785-802$.

- (I911). "Experimentelle Untersuchungen über die Fortpflanzungsverhältnisse bei Daphniden." Biol. Cent. 30, $81-85$.

PunNetT, R. C. (1906). "Sex-determination in Hydatina, with some remarks on parthenogenesis." Proc. Roy: Soc. Lond. B, 78, 223-23I.

REINHARD, H. J. (1927). "The influence of parentage, nutrition, temperature and crowding on wing production in Aphis gossypii Glover." Texas Agric. Exp. Sta. Bull. 353, 5-19.

von Scharfenberg, U. (19II). "Studien und Experimente über die Eibildung und den Generationszyklus von Daphnia magna." Int. Rev. d. ges. Hydrob. u. Hydrogr. 3 (Suppl. 3), 1-42.

_ ( 1914 ). "Weitere Untersuchungen an Cladoceren über die experimentelle Beeinflussung des Geschlechts und der Dauereibildung." Int. Rev, d.ges. Hydrob, u. Hydrogr. Biol. Suppl. 6, I-34.

Schmankewitsch, W. J. (1875). "Ưber das Verhältnis der Artemia salina Miln. Edw. zur Artemia mühlhausenii Miln. Edw. und dem Genus Branchipus Schaeff." Zeit. wiss. Zool. Suppl. to 25, 103-II5.

Schrader, F. (1925). "The cytology of pseudo-sexual eggs in a species of Daphnia." Zeit. ind. Abst. Vererb. $40(\mathrm{I}, 2), \mathrm{I}-27$.

Shinj, G. O. (1918). "A contribution to the physiology of wing development in aphids." Biol. Bull. $35,95-116$.

Shull, A. F. (19roa). "The artificial production of the parthenogenetic and sexual phases of the life cycle of Hydatina senta." Am. Nat. 44, 146-150.

- $($ I $910 b)$. "Studies in the life cycle of Hydatina senta. I. Artificial control of the transition from the parthenogenetic to the sexual method of reproduction." Fourn. Exp. Zool. 8, 31 I-354.

- (1911). "Studies in the life cycle of Hydatina senta. II. The rôle of temperature, of the chemical composition of the medium, and of internal factors upon the ratio of parthenogenetic to sexual forms." Yourn. Exp. Zool. 10, i $17-166$.

- (1912). "Studies in the life cycle of Hydatina senta. III. Internal factors influencing the proportion of male-producers." Fourn. Exp. Zool. 12, 283-317.

- ( $\left.\operatorname{Ig}_{3} a\right)$. "Eine künstliche Erhöhung der Proportion der Männchenerzeuger bei Hydatina senta." Biol. Cent. 33, 575-576.

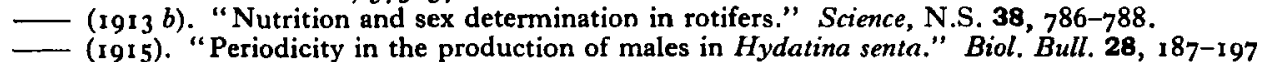

- ( $(1918 \mathrm{a})$. "Relative effectiveness of food, oxygen and other substances in causing or preventing male-production in Hydatina." Fourn. Exp. Zool. 26, 521-544.

- $(1918 b)$. "Genetic relations of the winged and wingless forms to each other and to the sexes in the aphid Macrosiphum solanifolii." Am. Nat. 52, 507-520.

-_ (1921). "Chromosomes and the life cycle of Hydatina senta." Biol. Bull. 41, 55-6r. (1922). "Relative nuclear volume and the life cycle of Hydatina senta." Journ. Exp. Zool. 35, 283-322.

(1923). "Sex determination in rotifers." Eugenics, Genetics and the Family. Scientific Papers of the Second International Congress of Eugenics, 1, $138-141$. (1925). "Sex and the parthenogenetic-bisexual cycle." Am. Nat. 58, $138-154$.

- (1926). "Life cycle in aphids affected by duration of light." Anat. Rec. 34, 168-169. (1928). "Duration of light and the wings of the aphid Macrosiphum solanifolii." W. Roux's Arch. f. Entw. d. Org. 113 (1), $210-239$.

- (1929). "The effect of intensity and duration of light and of duration of darkness, partly modified by temperature, upon wing-production in aphids." W. Roux's Arch. f. Entw. d. Org. In press.

Shull, A. F. and LadofF, Sonıa (1916). "Factors affecting male-production in Hydatina." Fourn. Exp. Zool. 21, 127-161.

von Sigbold, C. T. E. (1856). Wahre Parthenogenesis bei Schmetterlingen und Bienen. Leipzig, Verlag von Wilh. Engelmann, vi +144 pp., 1 pl.

Slingerland, M. V. (1893). "Some observations on plant lice." Science, 21, 48-49.

SMiTh, G. (1915). "The life cycle of Cladocera, with remarks on the physiology of growth and reproduction in Crustacea." Proc. Roy. Soc. Lond. B, 88, $4^{\mathrm{I} 8-435}$.

Sмiтh, R. H. (1923). "The clover aphis : biology, economic relationships and control." Idaho Agric. Exp. Sta. Research Bull. 3, 75 pp., 35 figs. 


\section{Determination of types of individuals in aphids, rotifers and cladocera 247}

Stevens, N. M. (1905). "A study of the germ cells of Aphis rosae and Aphis oenotherae." Yourn. Exp. Zool. 2, 313-333.

Storch, O. (1923). "Parthenogenese und Eireifung der heterogonen Rädertiere." Zeit. ind. Abst. Vererb. 30, 309-312.

- (r924). "Die Eizellen der heterogonen Rädertiere." Zool.Fahrb. Abt. Anat.u. Ont.45, 309-404.

Stroht, J. (1907). "Die Biologie von Polyphemus pediculus und die Generationszyklen der Cladoceren." Zool. Anz. 32, 19-25.

- (1908). "Polyphemusbiologie, Cladocereneier, und Kernplasmarelation." Int. Rev. d. ges. Hydrob. u. Hydrogr. 1, $821-832$.

Stschelkanovzew, J. P. (1904). "Uber die Eireifung bei viviparen Aphiden." Biol. Zent. 24, $104-112$.

TAUSON, A.O. (1924). " Die Reifungsprozess der parthenogenetischen Eier von Asplanchna intermedia Huds." Zeit. f. Zell. u. Geweb. 1, 57-84.

_- (1925). "Wirkung des Mediums auf das Geschlecht des Rotators Asplanchna intermedia Huds." Int. Rev. d. ges. Hydrob. u. Hydrogr. 13, 130-1 70, 282-325.

- (1926 a). "Uber die Wirkung des Mediums auf das Geschlecht des Rotators Asplanchna intermedia Huds. (Uber den Einfluss der aktuellen Reaktion, der Temperatur, und des $\mathrm{Ca}^{++}$ nuf Asplanchna intermedia Huds.)" W. Roux's Arch.f. Entw. d. Org. 107, 355-39r.

- (1926 b). "Nachtrag zu der Arbeit von A. O. Tauson, Wirkung des Mediums auf das Geschlecht des Rotators Asplanchna intermedia Huds." Int. Rev. d. ges. Hydrob. u. Hydrogr. 14, 339-340.

— ${ }^{339-340 .}$ (1927 a). "Die Spermatogenese bei Asplanchna intermedia Huds." Zeit.f. Zellforsch. u. mikr. Anat. 4 (4), 652-681.

- $(1927 b)$. "Uber die Wirkung des Mediums auf das Geschlecht des Rotators Asplanchna intermedia Huds. (Uber die Wirkung der Veründerung des Sauerstoffgehaltes und der Nahrung auf Asplanchna intermedia Huds.)" W. Roux's Arch. f. Entw. d. Org. 109.(3), 342-36r.

TAYLOR, M. (1914). "Note on the number of chromosomes in the male Daphnia pulex." Zool. Anz. $46,21-24$.

Turner, W.F. and BAKER, A.C. (1915). "The occurrence of an intermediate in Aphis pomi de Geer." Ent. Soc. Wash. Proc. 17, 42-52.

DE LA VAULX, R. (1915 a). "Sur des Daphnies androgynes." Bull. Soc. Zool. France, 40, $102-104$.

- $(1915 b)$. "Anomalies antennulaires de quelques daphnies gynandromorphes." Bull. Soc. Zool. France, 40, 194-197.

- (1919). "L'intersexualité chez un crustacé cladocère: Daphne atkinsoni Baird." Comp. Rend. Acad. Sci. Paris, 169, 97-99.

- (1921). "L'intersexualité chez un crustacé cladocère Daphnia atkinsoni Baird." Bull. scient. de France et de Belgique, 55, $1-86$.

- (1922). "Sur l'apparition d'intersexués dans une lignée de Daphnia magna (crustacé cladocère) et sur le déterminisme probable du phénomène." Comp. Rend. Acad. Sci. Paris, 174, 17401742.

WADIEY, F. M. (1923). "Factors affecting the proportion of alate and apterous forms of aphids." Ann. Ent. Soc. Am. 16, 279-303.

WatkA, MAx (1928). "Die Rotatorienfauna der Cakowitzer Zuckerfabriksteiche und Versuche über das Auftreten von Rotatorien-Männchen und über die Entwicklungszeit der Dauereier." Int. Rev. d. ges. Hydrob. u. Hydrogr. 19, 430-451.

Weismans, A. (1879). "Beiträge zur Naturgeschichte der Daphnoiden. VII. Die Entstehung der cyklischen Fortpflanzung bei den Daphnoiden." Zeit. wiss. Zool. 33, 1 I1-270.

Wesenberg-Lund, C. (1923). "Contributions to the biology of the Rotifera. I. The males of the Rotifera." Mem. Acad. Roy. Sci. Lett. Danemark, Copenhagen, Sec. Sci. Series 8, 4, 191-345.

WhitNey, D. D. (1907). "Determination of sex in Hydatina senta." Fourn. Exp. Zool. 5, 1-26.

- (1909). "Observations on the maturation stages of the parthenogenetic and sexual eggs of Hydatina senta." Fourn. Exp. Zool. 6, 137-146.

(1910). "The influence of external conditions upon the life cycle of Hydatina senta." Science, N.S. 32, 345-349.

— (1912). "Strains' in Hydatina senta." Biol. bull. 22, 205-218.

- $(1914 a)$. "The production of males and females controlled by food conditions in Hydatina senta." Science, N.S. 39, 832-833.

- $(1914 b)$. "The influence of food in controlling sex in Hydatina senta." Fourn. Exp. Zool. 17, $545-558$.

- (1915). "The production of males and females controlled by food conditions in the English Hydatina senta." Biol. Bull. 29, 41-45.

- (1916). "The control of sex by food in five species of rotifers." Fourn. Exp. Zool. 20, 263-296.

- $(1917 a)$. "The relative influence of food and oxygen in controlling sex in rotifers." Fourn. Exp. Zool. 24 101-138. 
WhITNEY, D. D. ( 1917 b). “The production of functional and rudimentary spermatozoa in rotifers." Biol. Bull. 33, 305-31 5.

-- ( 1918$)$. "Further studies on the production of functional and rudimentary spermatozoa in rotifers." Biol. Bull. 34, 325-334.

- (1919). "The ineffectiveness of oxygen as a factor in causing male-production in Hydatina senta." Fourn. Exp. Zool. 28, 469-492.

(1924). "The chromosome cycle in the rotifer Asplanchna intermedia." Anat. Rec. 29, 107. (1929). "The chromosome cycle in the rotifer Asplanchna amphora." Fourn. Morph. Phys. In press.

WOLTERECK, R. (1909). "Weitere experimentelle Untersuchungen über Artveränderung, speziell uber das Wesen quantitativer Unterschiede bei Daphniden." Verh. deutsch. zool. Gesell. 19, I10-172.

__ (I 1 I 1 ). "Uber Verănderung der Sexualităt bei Daphniden. Experimentelle Untersuchungen über die Ursachen der Geschlechtsbestimmung." Int. Rev. d. ges. Hydrob. u. Hydrogr. 4, 91-128.

- (1928). "Uber die Population Frederiksborger Schloss-See von Daphnia cucullata und einige daraus neuentstandene Erbrassen, besonders diejenige des Nemi-Sees." Int. Rev. d. ges. Hydrob. u. Hydrogr. 19, 172-203.

WoODWORTH, C. W. (1908). "Winged aphids." Ent. News, 19, 122-123.

Zawabowsky, M. (1916). "Delay in the formation of the egg and the determination of sex in Diglena volvocicola." Journ. russe de Zool. 1. 